ఠ

OPEN ACCESS

EDITORS

- Miguel Oliveira, Jr. (UFAL)

- René Almeida (UFS)

REVIEWERS

- Vítor Nóbrega (USP)

- Gabriel Othero (UFRGS)

DATES

- Received: 07/15/2020

- Accepted: 10/31/2020

- Published: 01/13/2021

HOW TO CITE

NEWMEYER, Frederick J. (2021). The Reception of Early Transformational Grammar In Europe. Cadernos de Linguística, v. 2, n. 1, p. 01-16.

\title{
THE RECEPTION OF EARLY TRANSFORMATIONAL GRAMMAR IN EUROPE
}

\author{
Frederick J. NEWMEYER (DD $\boldsymbol{D}$ \\ University of Washington | University of British Columbia | Simon \\ Fraser University
}

\section{ABSTRACT}

The early success in the United States of Chomsky's book Syntactic Structures and the theory of transformational-generative grammar that it introduced raises the question of the reception of the theory in other countries. Looking at Europe, there is no overarching generalisation. In some countries (the UK, the Netherlands) the theory enjoyed a great success, in others a moderate success, at least for a time (France, Germany), and in other countries very little success (Italy, Spain). Nevertheless, there is widespread agreement that European contributions to the theory have been among the most important.

\section{RÉSUMÉ}

Le premier succès aux États-Unis du livre de Chomsky Syntactic structures et de la théorie de la grammaire transformationnelle-générative qu'il a introduite pose la question de la réception de la théorie dans d'autres pays. En ce qui concerne l'Europe, il n'y a pas de généralisation globale. Dans certains pays (Royaume-Uni, Pays-Bas), la théorie a connu un grand succès, dans d'autres un succès modéré, du moins pendant un certain temps (France, Allemagne), et dans d'autres pays très peu de succès (Italie, Espagne). Néanmoins, il est largement admis que les contributions européennes à la théorie ont été parmi les plus importantes. 
KEYWORDS

European Linguistics; History of Linguistics; Transformational-Generative Grammar.

MOTS-CLÉS

Grammaire Transformationnelle-Générative; Histoire de la Linguistique; Linguistique Européenne. 


\section{INTRODUCTION ${ }^{1}$}

In 1957, Noam Chomsky's book Syntactic Structures (Chomsky 1957) was released by the Dutch publisher Mouton. Syntactic Structures presented a novel theory of syntax, transformational-generative grammar (TGG), though one that was rooted in existing structuralist traditions - in particular American. As early as 1964 a commentator had written: '[T]ransformational grammar has established itself as the reference point for discussion of linguistic theory [...] it remains the case that it has been Chomsky who has effectively opened the American linguistic scene to its present free and fruitful discussion' (Hymes 1964: 25). A year later, there was talk of a 'Chomskyan revolution' in the field (Bach 1965: 111-112; Levin 1965: 92; Thorne 1965: 74). However, all of these references were by Americans, with one British exception.

The success of Chomsky's ideas in the United States raises the question of what efforts were made to 'internationalize' the theory. This paper addresses that question, at least with respect to Europe. However, two factors will lead unfortunately to a fairly superficial treatment: space limitations and the fact that there is no overarching generalization. Each European country needs to be examined separately.

\section{TGG IN EUROPE: SOME GENERAL REMARKS}

TGG was slow getting off the ground in Europe. With a couple of exceptions to be discussed below, very few European countries had active centres of generative grammar before the 1970s or later. It is still the case that some European countries have no more than a small handful of generativists. Indeed, the first collection of generative papers written and edited by European generativists did not appear until 1973 (Kiefer and Ruwet 1973), with contributions from the Netherlands, the United Kingdom, Poland, East Germany, West Germany, France, Hungary, the USSR, Sweden, and Romania. ${ }^{2}$ In his chapter, Manfred Bierwisch noted that there was nothing particularly distinctive about TGG, as practiced in Europe, remarking:

Although since the early sixties and increasing number of linguists in Europe have been attracted by the theory of generative grammar, they do not form in any serious sense a particular trend or

1 I would like to thank the following for their input on this paper: Werner Abraham, Gabriel de Avila Othero, Hans Basbøll, Manfred Bierwisch, Keith Brown, Niels Davidsen-Nielsen, Giorgio Graffi, Camiel Hamans, Martin Haspelmath, Peter Matthews, Carlos Otero, Pierre Pica, Annarita Puglielli, Maria-Luisa Rivero, Pieter Seuren, Henk van Riemsdijk, Nigel Vincent, Dieter Wunderlich, and one anonymous referee

2 However a few years earlier the East Germans Manfred Bierwisch and Karl Heidolph had edited a volume in which about half of the contributions came from Europeans (Bierwisch and Heidolph 1970). 
school of anything of this kind that could be contrasted to corresponding research that could be done elsewhere in the world. Hence the heading Generative grammar in western Europe does not specify a coherent and self-contained topic. (Bierwisch 1973: 69)

As we will see, in later years European generative work came to be seen as, perhaps not distinctive, but at least of higher quality than such work as practiced in the United States.

The most important event regarding TGG in Europe took place at a later time than is focussed upon in this article. I am referring to the founding of Generative Linguistics in the Old World (GLOW) in 1977, with the goal of furthering the study of generative grammar by organizing an annual spring conference and periodical summer schools, and by publishing a newsletter that discusses current intellectual (and organisational) issues in the field. The success of GLOW needs to be tempered by the realization that the world of European TGG is a small one indeed. In the words of Henk van Riemsdijk, one of the three principal founders of GLOW (along with Jan Koster and Jean-Roger Vergnaud):

\begin{abstract}
Looking back to the initial stages of GLOW, 20 years ago, I had something like an idea that that was the start and we would slowly conquer some power basis in Europe, not to become the only game in Europe, but at least one of the major ones. I think many generativists, especially young ones, tend to be quite mistaken about the extent to which that has been successful. The reason is that we have made some progress, we have centers where we attract students. These students get a good training, they go to conferences, the whole world in which they move is a generative world. But they often don't realize that it is an extremely small world. (van Riemsdijk 1998: 18)
\end{abstract}

While I have no statistics to back up my intuition, I believe that the International Cognitive Linguistics Association, when it meets in Europe, outdraws GLOW by a factor of two to one, and that more linguists in Europe consider themselves 'functionalists' than consider themselves 'generativists'.

\title{
2. TGG IN THE UNITED KINGDOM
}

The United Kingdom is TGG's biggest European success story. By the end of the 1970s most British departments had generative orientations. A summary statement by Peter Matthews indicates the ease of acceptance of TGG in that country:

If you are asking in effect if I, or others that I knew of, found it difficult as followers of Chomsky either to get a job or to teach the subject as we wished, the answer basically is no, not at all. (p. c., 12 March 2018)

Indeed, TGG had a presence in the UK even in the 1950s. Peter Matthews has written:

W. S. Allen's advice was that I should get a copy of Chomsky's Syntactic Structures (1957), published two years earlier. ... It was an eye-opener (2002: 201). In America [in 1963-1964 - FJN] I had come to know John Lyons and Jimmy Thorne, both near contemporaries, and, on returning to this country, two of us at least believed we were a triumvirate whose mission was to open colleague's minds to new, especially to Chomsky's early, ideas. (Matthews 2002: 205) 
Allen himself had the distinction of reading Syntactic Structures before it was even published. He recalls:

\begin{abstract}
In 1956 I saw a pre-print of Noam Chomsky's first major work, his Syntactic Structures, published in 1957. It seemed to me that this, with its transformational-generative approach, might provide a solution to Lyons's problem [of how to relate sentences occurring in different grammatical structures which one intuitively felt to belong together] - and so it proved to be. He successfully adapted and refined Chomsky's basic ideas to his own ends, his dissertation was duly completed in 1961 and was published in a revised form by the Philological Society in 1963 [= his book Structural Semantics - FJN]. (Allen 2002: 21)
\end{abstract}

Indeed, a glowing review of Syntactic Structures was John Lyons's first publication, where he found the book 'most interesting' (Lyons 1958: 109) and 'very convincingly argued' (p. 111). In the same volume as the abovementioned papers by Matthews and Allen, Lyons wrote:

I read Syntactic Structures in the early summer of 1957. This proved to be a turning point in my career. [Chomsky's work] helped me resolve the theoretical and methodological problems I was having with my research. At a later stage of my career, I developed a broader interest in generative grammar. (Lyons 2002: 174)

The Dutch linguist Pieter Seuren was another early contributor to TGG in the UK, introducing many students to generative grammar, who later went on to become prominent (though not necessarily in later years as generativists):

Fortunately, I was selected as a writer of a Dutch language course for English students at Cambridge University in 1966. There, the head of the new linguistics department, John Trim, immediately saw that I was not a language-course writer but a theoretical linguist. So he made sure that I was appointed to a lectureship in linguistics in his department. I also became a fellow of Darwin College. At Cambridge, we had an exceptionally good crop of students, including Bernard Comrie, John Hawkins, Nigel Vincent, Robin Cooper, Andy Radford and quite few other now well-known linguists. I once made a count and came to eleven linguistics professors who went through our department as students between 1966 and 1970. For those days, this was extraordinary. All these students were, as I said, steeped in the TGG of the late 1960s - although I myself was already veering towards generative semantics (becoming a good friend of Jim McCawley). The students largely abandoned TGG and went their own way, but for Andy Radford, who remained a staunch Chomskyan. ${ }^{3}$ (p. c., 13 July 2018)

Thanks in large part to Seuren's efforts, Cambridge was an important place of generative studies by 1970. However, he had much less success at Oxford, where he was a fellow of Magdalen College between 1971 and 1974. Oxford was then (and is now to a considerable extent) steeped philological and philosophical approaches to language, as opposed to purely grammatical ones.

3 While Hawkins, Vincent, and Cooper are not 'staunch Chomskyans' in the literal sense, their work complements Chomskyan conceptions, rather than oppose them. Comrie, on the other hand, became quite anti-generative. 
The UK, of course, was a leading centre of structural linguistics before 1957. One of the world's most prominent linguists between the 1930s and the 1950s was J. R. Firth, whose work on prosody anticipated generative approaches to that topic decades later. But Firth left no enduring organisationa/ legacy with a vested interest in developing his ideas. His leading student, Michael Halliday went off in his own direction to found the school of systemic-functional linguistics. Halliday was quite opposed to TGG from the beginning, but he left University College London (and the UK) in 1971. After his departure, the department there rapidly developed a generative orientation.

\title{
3. TGG IN THE NETHERLANDS
}

Another generative success story is the Netherlands. As one summary article put it: 'Zur Zeit gibt es an jeder Universität generative Forschung. Schwerpunkte gibt es in Groningen, Utrecht und Tilburg' (Haider et al. 1987).

Interestingly, Pieter Seuren had played a crucial role in the development of TGG there before he departed for the UK. As early as 1958 there was group led by Pieter Seuren and Rudolf de Rijk that was studying Syntactic Structures (Hamans 2015). Seuren recalls:

\begin{abstract}
I had set up an unofficial working party for the study of TGG on March 1st, 1958, the day after I took my MA-exam, by ringing up my good friend Rudolf de Rijk (died 2003), who at the time studied foundations of mathematics with Evert Beth together with linguistics, and who later became a very well-known specialist in Basque, and my friend and colleague Remmert Kraak (died 2005). Our little group was quickly extended with Wim Klooster and Henk Verkuyl (both still alive), and, as from 1962, with tens of others, among whom Jan Koster, Henk van Riemsdijk and practically all the other Dutch generativists of that generation. In the early 1960 s, we were about forty people, and our official head was Frits Staal, who had become a philosophy professor at Amsterdam University in 1962 and had immediately given our still unofficial group official university status. This group was the origin of the entire contingent of present-day Dutch generativists. The TGG we studied was, of course, still of the 'orthodox' kind, as generative semantics had not come about yet. I myself became a 'generative semanticist' after an intensive study of Katz \& Postal's 1964 Integrated Theory of Linguistic Descriptions, which we read and discussed in the working party. (p. c., 13 July 2018)
\end{abstract}

According to Henk van Riemsdijk, there were several reasons for the success of TGG in the Netherlands:

First, opposition to generative grammar was relatively minimal in Holland because the protagonists of the 'old guard' were not close, each pursuing his own 'theory'. Paardekooper was a true syntactician, his grammar of Dutch, though in a very idiosyncratic pseudoformalism, contains lots of important insights. Reichling was more a philosopher and semanticist than anything else. Uhlenbeck was mostly into exotic languages, in particular Javanese. Verburg was a bit like Reichling but also on his own, and De Groot was largely a structuralist grammarian. 'They were not so much fighting as ignoring each other. There was no Dutch Linguistic Society to speak of, let alone an attempt at creating a "school" as opposed to the Prague, Copenhagen and Paris Circles.

Second, The Dutch intelligentsia, at that time, tended to be quite liberal. ... Most typically, Simon Dik was Reichling's star student and naturally became his successor at an early age. When, in 1970, I came to Holland from Paris, he was happy to have me in his department, become his Ph.D. student, give me a job, etc. All this in spite of the fact that he was an anti-generativist while he knew full well that I was a Chomskyan. ... [Later] Simon Dik did want to get rid of me. But the way he did it was to support me very strongly in getting a full professorship, which was successful in 1981. (p. c., 20 February 2018) 
Van Riemsdijk in a 1990 paper added a few more reasons: The student upheavals of the 1960s led to more democracy, Holland's small size has made it international, open to new ideas, and the country has a long tradition of scientific publishing.

Henk Verkuyl gives a complementary explanation for the success of generative grammar in the Netherlands:

\begin{abstract}
There are countries in which generative grammar came, saw and lost, as in France, Spain, and some other European countries. My main thesis is that generative grammar has been successful in the Netherlands due to a conjunction of three factors: (a) there was an internationally recognized strong philosophical-logical tradition which helped it through its first stage; (b) the linguistic establishment of the fifties and sixties was rather weak and quite incoherently organized into local schools; (c) at the peak of the generative success the universities needed a lot of people so that a lot of places could be filled by young generativists. (Verkuyl 1990: 2-3)
\end{abstract}

\title{
4. TGG IN FRANCE
}

The situation in France could not be more different from that in the UK and the Netherlands. After a promising start, generative grammar went into retreat in France.

Today there are scattered centres of generative grammar (mostly in Paris ${ }^{4}$ ), but the theory as a whole cannot be said to be doing well.

TGG in France took off with the arrival of Richard Kayne from MIT at Paris VIII (Vincennes) in 1969, whose charisma, articulateness, and great rapport with Chomsky acted as a lightning rod for the attraction of a group of young generativists. ${ }^{5}$ Lectures given by the MIT-trained Joseph Emonds a couple of years later also played an important role. New faculty and many students (French and international) migrated in France in the 1970s (mostly to several Parisian universities). Some of the most important publications in generative syntax date from that period. But several factors reversed the gains starting in the late 1970. Perhaps the most damaging was the 'defection' of several leading (and influential) French generative grammarians: Maurice Gross, Jean-Claude Milner, and Nicolas Ruwet. Gross, Milner and Ruwet, highly influenced by Marxism and French phenomenology, were never comfortable with the explicitly biological 'language organ' approach of Chomsky's. As Pica and Rooryck (1994) observe (I think correctly), that the French, in general, favour 'external' theories, not 'internal' ones.

Pica and Rooryck (1994) give several other reasons why the early promise of TGG in France was not fulfilled. First, the comprehensive grammar of French, the main goal

4 Haider, Prinzhorn, and van Riemsdijk (1987: 476) wrote that Paris is the European city with the greatest number of generative grammarians. I doubt that such is true today.

5 However, Hamans (2015) feels that Chomsky exaggerates the importance of Kayne in the development of French TGG. 
in the 1970s, was never completed. Second, French publishers have always been reluctant to publish in generative grammar. Third, French generativists never learned to navigate the waters of the French educational system. And fourth, the existence of a stronger anti-Americanism than in most European countries led to suspicion of an American-orginated theory.

In a personal communication (1 March 2018) Pierre Pica elaborated on the remarks that he and Rooryck had made over a decade earlier:

In my opinion, the French situation is due to many factors, the most important of which are the following two: The influence of Marxism was strong in France and the idea that language could be reduced to a biological faculty was totally misunderstood (say, by Jean-Claude Milner). Secondly, European structuralism was also strong, partly because of its association with Marxism through the dialectic. The problem was that at least in France most people interpreted Syntactic Structures as a follow up on [mathematically-oriented] work by Maurice Gross and by Chomsky and Schützenberger. When they realized it was going in another direction, they did not like it at all. Nicolas Ruwet's case is a variant of the same thing. A cultivated man as he was, was not very interested by the subtleties of the linguistic data (see his book Syntax and Human Experience [Ruwet (1991)]).

There is a third factor that no one speaks about: the rigidity and old fashioned style of French institutions, where students did not have scholarships, office hours and the like. It was just impossible for a normal student to work in these conditions, so generative grammar could only develop in more sophisticated circles like an école normale or an école polytechnique. The reason I mention all this, is that although the situation has changed, the main factors are still there. Semantics is accepted because it is formal (not associated to the mentalist issue), but very few people do real syntax. When they do syntax, they are really doing psycholinguistics. A huge part of linguistics is absorbed by neuroscience (again away from the mentalist vs. nonmentalist issue). Note that France has a huge sector of linguistics dedicated to the study of languages across the planet, most of it mainly descriptive/functional linguistics. This sector remains opposed to more theoretical studies.

\section{TGG IN GERMANY}

Germany was divided until 1989 and so was the reception of TGG. Nowhere in Germany was there a strong structuralist tradition. That fact both impeded and facilitated TGG in Germany. 'Impeded' since it was not taken for granted that there was a structuralist core to grammar. 'Facilitated' since there was no dominant structuralist approach to oppose TGG.

TGG had more initial success in the East than in the West. Wolfgang Steinitz and Manfred Bierwisch were instrumental in the Arbeitsgruppe Strukturelle Grammatik in East Berlin, where much work in TGG took place in the 1960s. American generativists gave lectures in East Berlin (1961) and Magdeburg (1964). The following is Manfred Bierwisch's personal recollection of events:

The Arbeitsgruppe Grammatik at the East Berlin Academy of Sciences, which I had joined in 1958, was one of the first places in East and West Germany, where the importance of Syntactic Structures was recognized right away. I still remember being impressed by the booklet (and by Bob Lees' programmatic review of it in Language [Lees (1957)]) in the late fifties. The ASG (= Arbeitsgruppe Strukturelle Grammatik, as it was called later on, indicating its largely quite suspect structuralist orientation) had been initiated by Wolfgang Steinitz in the mid-fifties and the connection between Jakobson and Steinitz, who used to be the vice-president of the Academy, was sort of situational background, which originated in pre-war times and had nothing to do with generative grammar. As a matter of fact, I wrote a dissertation that was very much 
influenced by Jakobson and Hjelmslev. The fascination with TGG came only with Syntactic Structures and Lees' Grammar of English Nominalizations [Lees (1960)]. Contact by mail with Chomsky brought us extensive comments on our first (still very tentative) attempts in the new framework.

Second, in 1961, right after the Berlin Wall, we had a small conference in East-Berlin, which Bob Lees attended (and in fact dominated), bringing the top news from MIT. This was instrumental for my Grammatik des deutschen Verbs [Bierwisch (1963)], which was, I believe, the first attempt to apply principles of TGG to German (simultaneously with an early study of Emmon Bach in Language). These attempts, by the way, established the view of German as a verb-final language. Connections with Hungarian colleagues (Kiefer, Szépe) were helpful in further developments, which led to the dominating role of TGG at the second symposium 'Zeichen und System der Sprache' in Magdeburg (which, by the way, had a predecessor 1959 in Erfurt, which was still completely pre-generative, where Jakobson, however, at least mentioned Chomsky). In 1962 we started the series Studia Grammatica, which was intended as a forum for TGG.

Third, the conference in Magdeburg 1964 was attended a.o. by Ed Klima, Haj Ross, Bruce Fraser, and I believe Paul Kiparsky. Chomsky, who was strongly invited to give a key address, did not participate, but had authorized Bruce Fraser to present central chapters from Aspects of the Theory of Syntax, which was by then in preparation. In a way, Magdeburg was the initial occasion for the 'standard theory' to start its successful career in Germany.

Fourth, after a couple of years of successful work in Generative Grammar in various place, especially the linguistics department at the University of Leipzig, and of course at the ASG, a fairly strange ideological campaign against GG in general and Chomsky's 'biologism' in particular was launched by the Communist Party in the GDR in 1968, which caused a lot of trouble, and did almost, but not quite, end research in TGG at the East German Academy. But that was long after Syntactic Structures and Aspects, a German translation of which, produced in the ASG, had appeared simultaneously with Suhrkamp and the GDR-Academy publishing house. (p. c., 17 February 2018)

Unfortunately, Steinitz died young and Bierwisch, being at a research institute, was not able to set up a program (Hamans 2015). After the Communist Party's intervention, described by Bierwisch, generative grammar stagnated in the East until reunification.

In West Germany in the late 1960s, TGG was attractive to a group of advanced graduate students (Dieter Wunderlich, p. c., 15 February 2018). Shortly later; they organized yearly meetings called Lingustisches Kolloquium, which attracted students from Denmark and the Netherlands (and more European countries in later years). However in West Germany and later in Germany as a whole, TGG has never had more than a small foothold. In the words of Henk van Riemsdijk:

Take a country like Germany. It is not a poor country, they've got a lot of universities. But if you want to pin point the centers of generative grammar, depending on your generosity, you end up with maybe half of a dozen. ... But, take Germany again, it is people in discourse analysis and pragmatics and so on that are in power. (van Riemsdijk 1998: 18)

Van Riemsdijk could have also mentioned formal semantics, which has many practitioners in Germany. There are actually quite a few German generativists, but they tend to be scattered around the country.

\section{TGG IN THE SOVIET UNION}

The story of the development of TGG in the Soviet Union can be described as 'curious'. In many parts of Europe, TGG was rejected because it was too formal. Consider by way of 
example a quote from André Martinet, commenting on a 1950s submission by Chomsky to the journal Word.

[Chomsky's submission is] a reaction against the self-imposed limitations of the Bloomfieldian approach, but one retaining all of its formalistic prejudices with a few additional ones. [...] Actually, my impression was one of utter drabness unrelieved by any glint indicating some hidden awareness of what a real language is. (quoted in Murray 1980)

But in the Soviet Union, TGG was accepted (for a short time) because of its being highly formalized. In an article published in Word in 1962, the leading Soviet linguist N. D. Andreyev made many positive remarks about TGG, given his belief that it could advance mathematical linguistics. This idea is confirmed in the following quote from Milka lvić, in an early historiography of the field: 6

Generative grammar, although it arose in the U.S.A., has been enthusiastically received in the Soviet Union, primarily because of its possible applications in machine translation. (Ivić 1965)

But by the 1970s the psychological and philosophical implications of Chomsky's ideas led TGG to be disfavoured by the academic establishment. The two leading Soviet generativists were to emigrate to North America, Shaumyan in 1975 and Mel'čuk a year later. ${ }^{7}$ According to Haider et al. (1987: 481), there was only one generative grammarian left in Russia at that time, a scholar based in Kaliningrad.

\title{
7. TGG IN ITALY
}

TGG was slow getting off the ground in Italy. Annarita Puglielli recalls:

\begin{abstract}
I believe that the first time Syntactic Structures was introduced in an Italian University was in 1960/61 when a seminar was held by Prof. S. Sacks from Berkeley University for students at the Università la Sapienza in Roma. I was studying at that time and 'happened' to register for that seminar that was optional and not part of any official course. There was a special program financed by the Ford Foundation that brought for some years American linguists in our Faculty with the aim of improving the linguistic knowledge of language teachers. The only linguistics taught at the time in Italian universities was historical linguistics and there were few places where structural linguistics (Saussure etc.) was talked about. I doubt that Syntactic Structures had been introduced in university courses before 1969 when I started to teach Linguistics in Rome. In 1967 the Società di Linguistica Italiana was started and in 1969 the first congress on
\end{abstract}

6 Around the same time, the historiographer of linguistics Maurice Leroy made a parallel observation:

... N. Chomsky, in particular, has undertaken a far-reaching analysis of grammatical structure by working out a formalization of linguistic levels according to the methods of formal logic. Studies such as these have proved especially valuable for the practical purposes of language teaching. They are also at the basis of applied linguistics, one of whose most spectacular achievements, brought about by the collaboration of linguists with mathematicians and technicians, is undoubtedly the development of machine translation. Work on these lines has gone ahead particularly in Russia and the English-speaking countries ... (Leroy 1963/1967: 81)

7 As noted in Everaert and Reuland (2011: 867-86), however, neither Shaumyan nor Mel'čuk had any commitment to the psychological aspects of the theory. 
generative grammar and its application to the description of Italian was organized. The spread of the theory found and still finds strong resistance in the Italian academic world, but over the years several linguists adopted this theoretical approach with very good results and contributed to its diffusion and development. (p. c., 21 February 2018)

Indeed, I think that it is fair to say that no country more than Italy has produced as many notable generative grammarians with as few programs and resources devoted to that theory. In the words of Giorgio Graffi:

\begin{abstract}
I hope I won't be accused of chauvinism (an attitude which I consider to be among the most detestable in the world) if I assert that the prestige of Italian generative linguistics is remarkable, not only on a European level, but on a world-wide level as well; as they say, 'the facts speak for themselves': the current president of GLOW is Italian, the European editors of Linquistic Inquiry are Italian, many books by Italian authors are present in the major international collections of literature on generative grammar. (Graffi 1990: 147)
\end{abstract}

It is also worth pointing out that the Government-Binding Theory (Chomsky 1981) was born in Pisa in 1979, as a result of a series of GLOW lectures given by Chomsky at the invitation of Luigi Rizzi and Adriana Belletti.

\title{
8. TGG IN CZECHOSLOVAKIA
}

Czechoslovakia (later the Czech Republic and Slovakia) provides an example of how the existence of a strong structuralist tradition impeded the development of TGG ${ }^{\text {. Perhaps the }}$ most flourishing school of structural linguistics in the interwar years was developed by scholars associated with the Linguistic Circle of Prague. Though the school was partly crippled by the Stalinist regime after the war, the general feeling was that the Czechs did not 'need' a new theory emanating from the other side of the ocean. As in the Soviet Union, it was the mathematical and computational implications of the theory that attracted the most interest, rather than the cognitive implications (Everaert and Reuland 2011: 5). After the Prague Spring, conditions became more difficult even for the leading Prague School linguists Petr Sgall and Eva Hajicova. Today, it must be acknowledged, the Czech Republic is not a leading centre of linguistics of any variety. Henk van Riemsdijk has offered the opinion that

\footnotetext{
the Prague school hasn't led to any significant insights for 30 years now. So that it makes no sense and you can see that the younger generation would actually like to do other things, like generative grammar, or formal semantics. They would love to be part of an international enterprise, which they don't get to be because their superiors tend to be rather fierce and control the jobs. So they have to do Prague school. So what you see is that the younger generation give talks in which they sort of disguise what they really want to do under a lot of Prague school terminology. (van Riemsdijk 1998: 19)
}

8 The Pragueans, like many European linguists at the time, considered themselves both 'structuralists' and 'functionalists'. 


\section{TGG IN DENMARK}

Denmark is another example of a country where a preexisting structuralist tradition (in this case glossematics) acted as an impediment to the development of TGG. Niels DavidsenNielsen, who wrote the first Danish generative-oriented paper in 1968, recalls:

As a whole there was great disagreement between linguists in Denmark about the new type of grammar from America. One important reason for that was undoubtedly that many of them continued clinging on to Glossematics and being loyal to Louis Hielmslev. (p. c., 15 February 2018)

Hans Basbøll concurs, writing:

I think the Chomskyan revolution (nightmare according to Martinet) was less strong in Denmark than in the other Scandinavian countries, due to the strong position of Glossematics in [the Copenhagen Linguistic Circle (CLC)] and Denmark more generally, at the time. I remember Henning Spang-Hanssen (well known for works within and around Glossematics, Professor of Mathematical and Applied Linguistics), gave a talk in CLC on 'Quid novi ex Chomsky?'. He discussed Syntactic Structures in his lectures in the sixties, I recall. I remember there were a number of young linguists in the sixties who were interested in TG, but typically, they knew structural linguistics well. In Sweden, there was not a strong structuralist tradition - despite Malmberg - but mainly a more traditional philological tradition. (p. c., 15 February 2018)

\section{TGG IN NORWAY}

Norway, on the other hand, with no home-grown structuralist tradition, has come to rival the UK and the Netherlands in the amount of generativist research carried out. The Centre for the Advanced Study in Theoretical Linguistics (CASTL), based in Troms $ø$, has become a destination for generative grammarians from all over the world.

\section{TGG IN SPAIN}

Demonte et al. (1982) point to the 'slow development' of TGG in Spain and of the 'isolation' of Spanish generativists. María Luisa Rivero and Violeta Demonte discuss aspects of the early reception of the theory in Spain (p. c., 1 March 2018):

\footnotetext{
In the late sixties, generative grammar begun to be discussed, among topics in philosophy, literature, and linguistics, in an informal gathering (Spanish tertulia) called Círculo Lingüístico de Madrid The participants were Agustín García Calvo (1926-2012), a well-known classicist and poet, Carlos Piera (b. 1942), a linguist and now well-known poet who was a student at the time and went on to get a Ph.D. in linguistics at UCLA, Rafael Sánchez Ferlosio (b. 1927), a very famous and much honored literary author (whose best known novel is El Jarama) and grammarian, and Victor Sánchez de Zavala (1926-1996), an engineer, philosopher, and linguist who would go on to play a crucial role in all activities concerning generative grammar in Spain in later years.

In 1967, very prominent Spanish intellectuals with a leftist orientation created a Centro de Enseñanza e Investigación (CEISA) (Center of Teaching and Research) to modernize academic
} 


\begin{abstract}
life in Spain, during the very dark period of the Franco regime. Within a Sciences and Humanities course offered by this center from February 1967 to May 1967, Carlos Otero Pelegrín spoke on 'Lingüística transformacional'. Víctor Sánchez de Zavala participated in the activities of this center, and so did Ernesto García Camarero, a mathematician who would be the vice-chair and later the chair of the Centro de Cálculo of the University of Madrid beginning in 1968, a site of many activities on generative grammar in the following years. The Centro published a regular Bulletin that included articles on generative grammar. The Seminario de Lingüística Matemática, which would become a continuous and active forum for generative grammar, began at the end of 1968 at the Centro de Cálculo of the University of Madrid (later Universidad Complutense). This seminar ended in the summer of 1971.
\end{abstract}

Despite the above, TGG was never able to achieve a strong organizational presence in Spain. As in other countries, there have always been outstanding generative grammarians in Spain, but they tend to be isolated and scattered across the country.

\title{
12. TGG IN PORTUGAL 9
}

Until the 1970s, language studies at Portuguese universities were mainly philological in nature. Structuralism never got a real foothold in Portugal. There were thus no strong theoretical barriers to TGG, which explains its relatively easy path in Lisbon and, to some extent, in Porto (but not in Coimbra, which had a very closed philological tradition). In fact, the institutionalisation of TGG at the Romance Philology Department of the Faculdade de Letras da Universidade de Lisboa (RP/FLUL) would have been considerably more difficult without the support of the (arguably) most important Portuguese philologist at the time, Luis Filipe Lindley Cintra, then a 'Catedrático' Professor at RP/FLUL. His moral and administrative assistance in the early 1970s both in the formation of Grupo de Estudos de Linguística Teórica (GELT) and in the creation of linguistics courses with a TGG perspective at RP/FLUL was invaluable.

In 1968, Maria Helena Mateus (who held a teaching position at the Romance Philology Department of RP/FLUL) and José António Meireles (then a student at RP/FLUL) started meeting informally in Lisbon to discuss TGG, until then practically unknown in Portugal. They were joined at the end of 1969 by Eduardo Raposo, also a student at RP/FLUL. In 1970, Meireles, Raposo, and Isabel Faria (also a student at RP/FLUL) formed a group dedicated to the study of TGG, namely, GELT, which had an office at the Centro de Estudos Filológicos (later renamed Centro de Linguística da Universidade de Lisboa). GELT organised collective discussions of topics in Portuguese syntax as well as readings of works in TGG such as Syntactic Structures, Aspects of the Theory of Syntax (Chomsky 1965), and Nicolas Ruwet's Introduction à la Grammaire Générative (Ruwet 1966) - a book which was instrumental in the TGG training of GELT members. Later, other students from RP/FLUL joined GELT, among

9 The information in this section was kindly provided by an informant who wishes to remain anonymous. 
whom were Inês Duarte, Ana Brito, Gabriela Matos, Fátima Oliveira, Amália Andrade, and Manuela Âmbar. It is also worth mentioning the attendance by GELT members at the Linguistic Institutes of the Linguistic Society of America (1972, 1974, and 1978), as well as at the IV International Summer School in Pisa in 1977, which facilitated the inclusion of the Portuguese linguists in the international TGG network and produced very fruitful contacts with linguists such as John R. Ross, David Perlmutter, Paul Postal, Luigi Rizzi, and Guglielmo Cinque, among others.

In the early 1970s, the first 'licenciatura' dissertations in generative syntax appeared: Meireles in 1972 (on complementation in Portuguese), Raposo in 1973 (on the inflected infinitive), and Faria also in 1973 (on the subjunctive mood). In 1972, Meireles was given a teaching position at RP/FLUL, followed by Faria and Raposo in 1973. Together with Mateus (who taught phonology), they started teaching syntax and semantics within a TGG framework. Later on, Duarte, Brito, and Oliveira were hired by the Faculty of Letters of Porto, where they were instrumental (together with Óscar Lopes, a Professor of Literature with strong interests in both linguistics and logic) in introducing TGG there. From this point on, TGG was on its way to becoming a central framework in the linguistics curricula in both Lisbon and Porto (and was arguably the dominant framework at RP/FLUL). This was facilitated by the publication in 1975 of an annotated translation of Aspects by Meireles and Raposo, and by Raposo's book Introdução à Gramática Generativa: Sintaxe do Português (Raposo 1978), in the sense that both works helped make TGG available to students with little or no knowledge of English.

\section{CONCLUSION}

Let me conclude by pointing to an interesting paradox: The achievements of European generative grammarians are vastly out of proportion to the number of practitioners, as compared to the United States. In an interview conducted by me in 1979, Chomsky made the following startling statement:

When I think of who around the world truly understands what I am trying to accomplish, I would have to say that all but about one or two are Europeans. (Noam Chomsky, p. c., 1979)

Along the same lines, a few years later Chomsky wrote: 'There is a far more material that I read with interest than was ever true in the past. Most of it comes from Europe, in fact, ...' (Chomsky 1982: 69). And more recently, the Dutch linguist Hans Bennis made a compatible observation:

If you were to make a list of the 50 most important contributors to generative grammar today, about 40 would be Europeans. (Hans Bennis, p. c., 2002) 
How might one explain the paradox? Perhaps it is the case that most European generative grammarians, being in the minority, have to work harder and therefore have produced more results. Perhaps their physical distance from MIT has worked to European generativists' advantage, given that it has left them more 'on their own'. Or perhaps the European scholarly tradition has played a role. The explanation of this paradox (if it has one) is for future research.

\section{REFERENCES}

Allen, W. Sidney (2002), 'Personal history', in Keith Brown and Vivien Law (eds.), Linguistics in Britain: Personal histories (Oxford: Blackwell), 14-27.

Bach, Emmon (1965), 'Structural linguistics and the philosophy of science', Diogenes, 51, 111-28.

Bierwisch, Manfred (1963), Grammatik des deutschen Verbs (= Studia Grammatica, vol. 2) (Berlin: Studia Grammatica).

Bierwisch, Manfred (1973), 'Generative grammar and European linguistics', in Ferenc Kiefer and Nicolas Ruwet (eds.), Generative grammar in Europe (Dordrecht: Reidel), 69-111.

Bierwisch, Manfred, and Karl Heidolph, eds. (1970), Progress in linguistics (The Hague: Mouton).

Chomsky, Noam (1957), Syntactic structures (Janua Linguarum Series Minor, 4; The Hague: Mouton).

Chomsky, Noam (1965), Aspects of the theory of syntax (Cambridge, MA: MIT Press).

Chomsky, Noam (1982), The generative enterprise: A discussion with Riny Huybregts and Henk van Riemsdijk (Dordrecht: Foris).

Demonte, Violeta, García-Billido, Paloma, and Mascaró, Joan (1982), 'Generative grammar in Spain', GLOW Newsletter, 9, 11-14.

Everaert, Martin and Reuland, Eric (2011), 'Generative grammar in Europe: Some historical impressions', in Bernd Kortmann and Johan van der Auwera (eds.), The languages and linguistics of Europe: A comprehensive guide (Berlin: de Gruyter Mouton), 867-86.

Haider, Hubert, Prinzhorn, Martin, and van Riemsdijk, Henk (1987), 'Syntaxreport - Generative Grammatik in Europa: Report on generative grammar in Europe', Folia Linguistica, 21, 471-87.

Hamans, Camiel (2015), 'How Generative Grammar landed in Europe', in Gerda Haßler (ed.), Metasprachliche Reflexion und Diskontinuität - Wendepunkte, Krisenzeiten, Umbrüche (Münster: Nodus Publikationen).

Hymes, Dell (1964), 'Directions in (ethno-)linguistic theory', in A. K. Romney and R. G. D'Andrade (eds.), Transcultural studies in cognition (American Anthropologist 66:3, part 2) (Washington: American Anthropological Association), 6-56.

Kiefer, Ferenc and Ruwet, Nicolas (eds.) (1973), Generative grammar in Europe (Dordrecht: Reidel).

Lees, Robert B. (1957), 'Review of Syntactic structures by Noam Chomsky', Language, 33, 375-408.

Lees, Robert B. (1960), The grammar of English nominalizations (The Hague: Mouton).

Leroy, Maurice (1963/1967), Main trends in modern linguistics (Berkeley: University of California Press). 
Levin, Samuel R. (1965), 'Langue and parole in American linguistics', Foundations of Language, 1, 83-94.

Lyons, John (1958), 'Review of Syntactic Structures by Noam Chomsky', Litera: Studies in Language and Literature (Istanbul), 5, 109-15.

Matthews, Peter H. (2002), 'Personal history', in Keith Brown and Vivien Law (eds.), Linguistics in Britain: Personal histories (Oxford: Blackwell), 200-12.

Pica, Pierre and Rooryck, Johan (1994), 'On the development and current status of generative grammar in France : A personal point of view', in Carlos P. Otero (ed.), Noam Chomsky: Critical assessments (New York: Routledge), 117-145.

Raposo, Eduardo P. (1978), Introdução À gramática generativa: Sintaxe do Português (Lisboa: Moraes Editotres).

Ruwet, Nicolas (1966), Introduction à la grammaire générative (Paris: Plon).

Ruwet, Nicolas (1991), Syntax and human experience (Chicago: University of Chicago Press).

Thorne, James P. (1965), 'Review of Constituent structure by Paul Postal', Journal of Linguistics, 1, 73-76.

Van Riemsdijk, Henk (1998), 'GLOW 1978-1998', Glot International, 3, 18-19.

Verkuyl, Henk (1990), 'The contribution of the Dutch to the development of linguistics', in Flor Aarts and Theo van Els (eds.), Contemporary Dutch linguistics (Washington: Georgetown University Press), 1-22. 